\title{
Theory(ies) of Culture and Compassion: Indian Writers Call out Local and Global Politics Under the Pall of Covid-19
}

\author{
Priya Kapoor* \\ Department of International and Global Studies, Portland State University, Portland, OR, United States
}

Keywords: authoritarianism, south Asia, Indian essayists, discourse analysis, international and political communication, communalism, migration

"This economic slowdown is caused by a humanitarian crisis. It is important to view this from the prism of sentiments in our society than mere economic numbers and methods," he said.

(Manmohan Singh, former Prime Minister and architect of economic

liberalization in India in an interview with Biswas, 2020)

Of all the people I spoke to that day, including a group of Muslim tailors who had only weeks ago survived the anti-Muslim attacks, one man's words especially troubled me. He was a carpenter called Ramjeet, who planned to walk all the way to Gorakhpur near the Nepal border.

"Maybe when Modiji decided to do this, nobody told him about us. Maybe he

Edited by:

Birzescu Anca,

Xi'an International Studies University,

China

Reviewed by:

Chambers Claire,

University of York, United Kingdom

*Correspondence:

Priya Kapoor

kapoorp@pdx.edu

Specialty section:

This article was submitted to Political Communication and Society,

a section of the journal

Frontiers in Communication

Received: 02 October 2020 Accepted: 01 February 2021

Published: 18 March 2021

Citation:

Kapoor P (2021) Theory(ies) of Culture and Compassion: Indian Writers Call out Local and Global Politics Under the

Pall of Covid-19.

Front. Commun. 6:613622.

doi: 10.3389/fcomm.2021.613622

\section{INTRODUCTION: FROM THE CRISIS OF A LOCKDOWN TOWARD A THEORY OF COMPASSION}

An excerpt from Roy's essay "The pandemic is a portal" (2020), cited above, uniquely captures the shock of the migrant worker-citizen who, in a moment of vulnerability, is struck by the attitude of unconcern by the ruling cadre of politicians, unable to empathize with them at the time that the pandemic struck. "Maybe he [Indian Prime Minister Narendra Modi] doesn't know about us" is a poignant realization, laden with disbelief when spoken by the traveling carpenter featured in Roy's essay. This statement is far more direct than the ruminative "maybe when Modiji decided to do this, nobody told him about us." To this Arundhati Roy adds, "Us [emphasis mine] means approximately 460 million people." In a recent interview with Manmohan Singh, an economist and former Prime Minister of India from 2004 to 2014, Biswas (2020) surmises that the lockdown was "hastily executed." Singh seems to tacitly condone Modi's shock-and-awe governance style during pandemic uncertainty saying, "perhaps the lockdown was an inevitable choice." Singh attributes the economic slowdown in India (see Gettleman, 2020) to Modi's March 24, 2020 decision. Manmohan Singh calls the decision out as a humanitarian crisis in no uncertain terms (Biswas, 2020; Dave, 2020). Statements culled from both the blue-collar worker and an eminent economist steer us into thinking about the health of our democracy. The power wielded by elected representatives almost define their [lack of] empathy in people-centered decisions and how those twin tropes (of democracy and elected representatives) are no longer descriptive of our current stock of callow global and local leadership. 
Once the Lockdown was announced at $8^{\circ} \mathrm{pm}$ on Indian television, the police got their orders to assert their authority to prevent citizens from movement within towns and cities. Several images of exercise in brute police authority circulated virally on social media and the press (Express News Service, 2020). Young men being beaten just because they were walking on the street going about their business, persons being jumped while traveling on their scooters and slapped without an explanation, became common sights on WhatsApp, Facebook and YouTube (Sharma, 2020). Vast numbers of migrant laboring persons found trains cancelled to their hometowns and when trains resumed several weeks later, they were overcrowded, either crushing them or excluding them (Gupta, 2020; Sen, 2020). Santosh Gangwar, the Minister of State for Labor and Employment, when asked in Parliament about documentation of migrant labor problems during the pandemic had barely any response to give as "data was not available on assistance provided to migrant workers" (The Wire Staff, 2020, np). Press reports that seven Members of Parliament asked if there was a count of migrant workers who had lost their lives. Gangwar, again, replied that no data was available. The Government floated several ration and employment schemes later to offset some of the damage done (The Wire Staff, 2020). The lives and the confidence lost, in Government goodwill, among migrant workers and their families is irreparable.

Many a philosopher or social thinker remarks that compassion is a desirable trait to harbor during a pandemic. Roy (2020b) alerts us to the exigency of caste intolerance that has led to the brutal, and fatal rape of a young Dalit woman at the hands of upper caste men. Mishra (2020), Sen (2020), and Appadurai (2020a) scrutinize the neocolonial and neoliberal structures adopted as economic policies that make our leaders indifferent to hunger, poverty, and dereliction among migrants from rural areas and in the global South (as in the United States and Europe), looking for work in the city. Given the urgency of the situation, is it possible to have a working theory of compassion during the months that Covid-19 takes up the major part of our consciousness while we field or tame the virus through our resources and everyday tactics. Protective gear, remote methods of paid work and a disruption in routine tasks such as dental visits, doctor's check-ups, grocery shopping, meeting friends, conducting religious rituals, and dropping off kids for socially distant interactions are some tactics used to circumvent the Covid-19 virus. In these times of distress what are the emotional reserves we possess for allowing our hearts to melt with a smile from a stranger, be moved by a gesture of kindness, be caressed as a street cat sidles by our ankle emerging between our feet. Moreover, how do we instill concern into our political and social life by creating policy that is compassionate to mothers, to single men, to travelers, to immigrants, to "illegal" bordercrossers, to criminals, to pets, to wildlife? For us, as citizens, the personal is political and the political is deeply personal.

\section{Foregrounding Political Analysis by Roy, Mishra, Ghosh, Sen, Appadurai and Other Writers of Indian Origin During Covid-19}

As an ode to compassionate politics, this paper is a reading of essays by Indian writers who are writing in the backdrop of the Covid-19 pandemic marked by the first phase of the Lockdown initiated by Prime Minister Modi toward the end of March 2020 and then its subsequent lifting. The lifting of the lockdown occurred under deep political duress to jumpstart the economy, and the socio-political decisions that have followed are tantamount to political faux pas that, not just PM Modi but other global heads of State, namely President Trump in the United States and PM Boris Johnson in the United Kingdom, have performed. This convergence of poor governing behaviors is not happenstance as patterns of colonialism, imperialism, postcolonialism, liberalism and (post-1990s) neo-liberal thought have aligned the US and the United Kingdom with India (Ghosh, 2016; Goodman, 2020; Mishra, 2020; Roy, 2020c). I assume, for this essay that India's position as a powerful geopolitical and socioeconomic-cultural entity establishes its presence as a global thought leader. I have curated and presented the beginnings of an analysis of recent essays, interviews, response to essays, and commentaries by Arundhati Roy, Pankaj Mishra, Amitav Ghosh, Amartya Sen, and Arjun Appadurai whose essays and interviews are an important read as Covid-19 and other human-created tragedies continue to rage in India, Russia, Brazil, Sweden, United States and parts of Africa; and protests against state policies and historical injustices are widespread (Levantesi, 2020). These five social thinkers and essayists move easily between borders yet their research is grounded in India and social justice. Also, Indian writers command a sizeable global readership and the critique of present times (with regards economics, governance and democracy) is made richer by adding their voice to popular public debate. Their voices as political commentators are unique as they challenge the ideals of democracy (as practiced in India, mirroring policies in Europe/ United States) and adherence of the modern nation-state to neoliberal economy, both held as sacred doctrine by the strong economies of the West. It is absolutely essential that these debates are brought into the public sphere when Covid-19 is victimizing steeply rising numbers of people in India and most other parts of the world. And also, ideals of good governance are shattered by elected leaders who seem to be floundering to find stable strategies to check mortality and infection among their people. Even though India is diligently pursuing Covid-19 vaccine research for the common good, research by the Indian Council of Medical Research (ICMR) has been found to contain certain inaccuracies motivated by political partisanship (Lancet, 2020). Underreporting of burgeoning infections on the one hand and the relaxation of restrictions on businesses on the other, has led to a dangerous climate of optimism among the average Indian citizen, that the Lancet has termed "false optimism" (Lancet, 2020).

Democracy and neoliberalism have worked hand-in-glove, serving each other well, creating a cadre of elite in every culture and nation whether their geographical identification begs the designation: global North or South. The attention of these ruling elite has completely divested from the common good, from people's hardship, from death and disease, indeed compassion, when most needed (Appadurai, 2020). At the same time the essayists reviewed sharply critique the direction that Indian leadership is taking with regards Covid-19, public healthcare, protest, social inequity and justice (Appadurai, 2020a; Ghosh, 2016; Goodman, 2020; Mishra, 2020; Roy, 2020c). Modi has made it abundantly clear that despite the ferocity of advance 
of the Covid-19 infection among its citizens, the Hindutva ideology will triumph, compelling him to continue with building the Ram Janmabhoomi temple over the formerly decimated Babri Masjid by Kar Sevak (mostly Hinduidentified) enthusiasts. Other recently enacted Acts and Laws shaking the foundation of the constitution and the judicial system are: the passing of the Kashmir domicile law to promote what amounts to settler colonialism in Kashmir. There is also the previous blight of Article 370, that revokes the self-governance and legislative powers that Kashmir, a Muslim majority state has held since India's independence. Following the Shaheen Bagh protests and social mobilization against racist, anti-Muslim pogroms (Covid-19 struck and Trump visited India before the Lockdown), several acts of incarceration and intimidation of innocent citizens became commonplace as an ode to asserting authoritarian rule (The Wire Staff, 2020a; The Wire Staff, 2020).

Amitav Ghosh, 2018 Jnanpith literary Award winner, is the only writer who has not written a post-Covid essay that I know of but has been interviewed by many news-based and literary quarters for discussions presaging the modalities of climate change and political leadership as applicable to the Covid outbreak. His pre-Covid epic "The Great Derangement: Climate change and the unthinkable" in 2016 has given us considerable grist for the mill. The title of the book is formulated as an imperative. Our footprint on earth has caused extreme distress to the environment. Ghosh cites the Paris Agreement, "climate change is a common concern for human kind" (2016, p. 206). The extent to which we have created this distress, we are sure to come across as deranged to generations that inhabit the earth after us. In an interview with Sardesai (2020) on India Today TV, Ghosh while mulling the intertextuality between his latest climate inspired novel Gun Island and Cyclone Amphan, underscores that migration, displacement and climate change have internecine links. Ghosh argues that the political elite completely ignore climate disasters thereby dismissing the science of climate change and subsequent action, quite easily. To belabor the argument Ghosh gives the example of Cyclone Amphan, and the vast destruction to human and animal life in the ecologically fragile region of the Sundarbans in West Bengal. Although cataclysmic, the event does not warrant more than one mention during national parliamentary debates for the season. Ghosh's writing and interviews help us re-evaluate crises of pro-environment leadership in a Post-Paris Agreement era.

\section{The Rule of the Elite}

PM Modi's government asserts executive power in a number of ways. The passing of the Citizen Amendment Act, CAA, makes religion a necessary foundation for citizenship. The NRC, National Register of Citizens requires a mountain of documentation ranging from land ownership documents, ration cards and birth certificates that most citizens do not possess. This exercise has yielded approximately 1.9-4.0 million people in Assam stateless (BBC, 2019). The NPR or the National Population Register is one of the largest datagathering attempts that purports to consolidate the biometric project started with the foundation of the Aadhar card. The Registry project was to begin in April 2020 before Covid-19 struck. Modi, like other authoritarian leaders in Hungary (PM
Viktor Orban), Turkey (President Recep Tayyip Erdogan), Poland (Jaroslaw Kaczynski, leader of the Law and Justice Party) has sought to increase his executive powers (Khosla, 2020) over every governmental institution that has decision making legislative powers. A recent OP-ED piece in the New York Times by Indian constitutional scholar Madhav Khosla cites Princeton constitutional law professor Kim Lane Scheppele in contrasting the record of human rights violations among national leaders in recent history. Autocrats of today when compared with 20th century autocrats, level the same damaging impact as tanks and bullets of yore (Khosla, 2020).

The "new autocracies" of Narendra Modi, Donald Trump, Recep Tayyip Erdogan, Jair Bolsonaro, Boris Johnson, Viktor Orban, Putin, Rodrigo Duterte signal what Appadurai (2020, np) terms "'populism from above'-where the people are electoral tools for a mass exit from democracy." Appadurai believes that $20^{\text {th }}$ century thinker José Ortega y Gasset's average "mass man" bound by similar "tastes, dispositions, and values" was yielding to a new breed of elites whose protest is primarily against liberty, equality and fraternity, the ideals of liberal democracy. These protesting or "revolting" elite avoid any regulatory, deliberative, or procedural checks against their version of capitalism and if someone [most likely an elite of a different kind-perhaps highly educated] questions them, they call foul (Appadurai, 2020a). Appadurai inverts the notion of protest and revolt (usually an action against dispossession of rights) in the wake of this emerging elitism, to turn his gaze on those power elite who protest to avoid abiding by the rules of democracy. Continuing in this dead serious mock-heroic vein, Appadurai points out that the power bearing elite worldwide and in India unite in their "hatred of intellectuals, academics, artists, activists, socialists, feminists, admiration for capitalism so long as it is regulated only in their favour, and a hatred of democracy matched by their cultish pursuit of the voter (rather than the people)" (2020, n.p.). In Appadurai's account, global leadership as he has described it, has wrested control of the state machinery to change the reality of its voting public so as to suit their pecuniary ends undermining established structures of governance, judiciary, and secularism.

If one were to string the headlines of press articles reporting on Covid-19, we would be able to weave a shocking tale of the economic, religious, judicial inequalities that the Covid-19 period has created and brings to light on a daily basis. Here are some iniquitous scenarios that have unfolded before us: 39 billionaires were added to the US economy in the first 3 months of the pandemic; while more astute than previous years, the US Congress and legislators, were unable to bring-to-book the four Tech Giants (Amazon, Google, Facebook, and Apple) for their anti-trust practices (Noble, 2020). In more humbler contexts, many a daily-wage laborer died, dehydrated and hungry, walking to reach their villages in India as the

\footnotetext{
${ }^{1}$ Appadurai (2020) calls the current administrations of world leaders namely Narendra Modi, Donald Trump, Recep Tayyip Erdogan, Jair Bolsonaro, Boris Johnson, Viktor Orban (and many others) as "new autocracies" because they are not acting in Democratic ways and there are plenty of elite who seem to follow their policies.
} 
lockdown was announced by PM Modi. Many will face chronic hunger in weeks, months to come (Staff, 2020). Their families are succumbing to food shortages (Dave, 2020; Menon, 2020). Several hapless laborers returning home were reportedly crushed while sleeping over train tracks believing them to be unmoving and unoperational during the lockdown (Gupta, 2020).

\section{Globalization and its (Dis)contents}

Statistical reports about our differential lives are too many to tell. Unemployment, hunger, domestic violence, these figures stagger those of us who have studied Globalization with cautious optimism. Globalization promised to bring in the best wares, services, and job opportunities of the world to our doorstep. Our constantly peripatetic lives initially brought the glad consumption of rare gifts, the awareness of varied global customs via media or travel, circulating wealth, but also invisible pathogens that clung on to the new environs first, to take root and then, to thrive upon our bodies. The story of globalization gradually unfolds and unravels in this Covid-19 era. For instance, the strong economic partnership between Wuhan, China, and Italy also sealed their fate in terms of disease and mortality. Furthermore, as a globalized humanity, we allowed the creation of rules of trade and commerce so benefits were heaped onto select (read: elite) populations and industries in disproportionate ways. The occurrence of Covid-19 surprisingly further skewed the manner in which money and commerce thrived. Safety protocols of Covid-19, namely remote functioning and remote work, has given an unfair advantage to technological businesses. Billionaires have emerged overnight. Tech companies raked it in (Noble, 2020). On the flip side, minority and marginalized populations have become more vulnerable to high rates of infection than ever before (Sen, 2020).

Much has been seen and made of United States President Trump's unconcern, lack of heart and understanding, to lead the country toward health sustainability and equal public health accessibility. PM Modi, on the other hand has made a moral virtue of imposing strictures of physical movement, especially when managing dissent, upon populations in India, in the name of bringing back the health of the nation during the Covid-19 pandemic. The Shaheen Bagh mobilization that fought against Islamophobia, the muzzling of freedom of speech and people's protests was at its height right before the national lockdown in March. Modi needed a recovery to glory. He invited Trump all the way from the United States so that this staged event would divert the attention of the public and bring recognition and fame to each of the leaders', for its own sake. Amidst talk of hospitality, gauging from offerings of gold-leaf covered fruit for the Trump team visiting India, we lost the ability to have a public discussion of the arms and ammunition deals that India would broker with the US. When the lockdown was imposed it was without concern for migrant workers away from their villages that were already dried of resources, farming opportunities back home, and other paid work in Urban areas. The lockdown did not care to account for the bolt of food scarcity, hunger or the need for shelter that millions are currently facing in the absence of family or social monetary reserves. The urban landlords who rely on income from migrant workers feel their monetary and kindness reserves pinched and constrained by the slim profit margins they are making.
Pankaj Mishra begins his essay "Flailing States" with the forthright quote by Paul Valery from 1919 in the context of Europe's rout, "the abyss of history is deep enough to hold us all." A reminder of the excess of Empire, a departure from Grecian classical notions of statesmanship and Government, and a nudge to England and the US to abandon its illusion of grandeur and supremacy are the essay's key upshot. "The early winners of modern history now seem to be its biggest losers with their delegitimized political systems, grotesquely distorted economies and shattered contracts," claims Mishra. He calls out Trump and Johnson's narcissism about their notions of governance and capitalism, their moral superiority over China, Iran, Russia, and the big exposé regarding a poorly run public health system that favors only those with means. Timely and frequent testing for early detection of Covid-19 has become a pipe dream, holding back checking the skyrocketing virus infection rates. Mishra exhorts India to embrace, once more, the value of social, political and economic equality embodied by its early founders. Mishra warns India against running with the bulls of democracy and state-building à la United Kingdom and the United States as it has only led to racial, ethnic divisions. Even education did not prove to be a great leveler of difference as the upper castes received top education and the top jobs. India's adherence to the economic and political growth patterns of Anglo-America has succeeded in putting us behind most East Asian countries.

Sen begins his essay (2020) by recalling a song by Vera Lynn about meeting again and in the song recall from 1939, he ruminates what scenario awaits us beyond the pandemic. Will the world be any different just because of our shared crisis? The world did come together and the United Nations, IMF and the World Bank were founded in 1944-1945, Britain reduced undernourishment among its population, life expectancy increased and the first National Health Service hospital was founded in Manchester in 1948. Several inequities were bridged by these post World War II measures. Yet 3 million Indians died in the Great Bengal Famine in 1943 and the British Raj did nothing to prevent the famine nor death. Similarly, we find inequities during the Covid era-minority, underrepresented populations are dying at a faster rate than majority populations (Sen, 2020). Alas, our sense of social justice and equality (in healthcare access nor in combatting malnutrition, houselessness, etc.) has not evolved despite our common struggle against the virus.

Roy's latest essay in August 2020, "India's Day of Shame" is on Kashmir, a land disputed with Pakistan and now China (Aksai Chin), with a majority Muslim population. Roy focuses on the governmental push toward decimating the will of the land and its people by robbing them of a basic $21^{\text {st }}$ century right: that of telephony, connectivity, the internet, and the state's sovereign status via the passing of Article 370, in December, 2019. Writing a year past Article 370 and the Citizenship Amendment Act (CAA), on August 05, 2020, just as the domicile law becomes viable, Roy awakens us to the displacement this law will cause for bona fide Muslim Kashmiris. The domicile law passed in the union territory of Jammu and Kashmir by the Bharatiya Janata Party-led Central Government faces a legal challenge posed by petitioners in the state (Maqbool, 2020). The law was enacted by the Ministry of Home Affairs through an executive order in March 2020, during Covid-19, promising "domiciles" jobs. The new domiciles would include all those who choose to relocate to J\&K without the 
traditional ties of culture and family. Reporter Umar Maqbool of the Wire writes, "before the reorganization of J\&K, non-locals were not eligible for jobs in the erstwhile state due to special constitutional safeguards incorporated in the constitution of India through a presidential order of 1954" (2020, np). It is estimated that 25,000 persons had already been granted domicile under the new rule enabling them to apply for jobs, own property and to vote (Connah, 2020).

This holding pattern of suspension of fundamental rights and the continuing house arrest of formerly elected pro-India state government officials and protesters has not changed in 1 year. The new domicile law of August 2020 leads to speculation on who will buy property in Kashmir. Purchase of land will displace Kashmiri citizens in a formerly constitutionally, legally independent state into a play ground of the rich and famous who will move there for profit and Himalayan cool air. Kashmir is often known as India's Switzerland and Bollywood song sequences are shot in its vales and lotus studded lakes. This law does not empathize with the myriad atrocities faced by the Muslim population who have deep generational roots in Kashmir and are the majority population living in the state. The Kashmiri Pandits, largely Hindu comprise approximately $2.5 \%$ of the total original residents of Kashmir and also stand displaced. The Kashmiri Pandits are dispossessed of ancestral land as well but have not been targeted by police and army authorities accused by human rights record keepers, of rape and torture, nor recruited by border terrorist organizations in the same way that the Muslim youth have.

The media often plays a polemical role with regards Kashmir reportage. In creating binary opposition, the media usually present two stark polarities comprising people on one side and the governmental bodies on the other signifying different purposes and intentions. Wellknown Qatari news outlet, Al (2020) inadvertently stoked a controversy regards domicile when it initiated a Tweet asking its listeners the question: "Are you in India and planning to move to Jammu and Kashmir under the recently introduced domicile laws? What's behind your decision? Send your thoughts for Sundays @ AJ STREAM" (Live on YouTube) (Al, 2020). With this question, Kashmiris were moved to call out Al Jazeera for promoting settler colonialism. Having created a stir, and wanting to initiate a serious debate on the issue, they invited Mona Bhan from Syracuse University, Mirza Saif Beg, a Kashmiri lawyer and Safwat Zargar, a Kashmiri journalist, all of whom comment on the downside of using incentivizing language in the tweeted question asked by the $\mathrm{Al}$ Jazeera tweet regards domicile law, initiating a general move to reside in Kashmir. The Al Jazeera call in tandem with the new domicile legislation against Kashmir seeks to "invisibilize" Muslims, says Mirza Beg (Al, 2020). This incident provides insight into how emotionally and physically destabilizing unchecked media intervention can be, especially this call for public "opinion" by Al-Jazeera that doesn't allow Kashmiris to weigh in about their existential condition prior to going live.

\section{On Compassion: Syncretism and Cultural Praxis}

The Kashmiris have lost their position of autonomy in the constitution despite protest of all hue, and in the North-East, Bengali-speaking immigrants have lost their locus standi in
Assam. The National Registry of Citizens has made almost 3 million Muslim immigrants who have lived for generations in Assam, lose their legal status (Roy, 2020a). The poignancy of their dilemma is hard to understand in standard prose and so writers who call themselves the Miyah poets of Assam have begun to pen down poetry that describes the othering process and injustice felt deep inside by Bengali-speaking Muslims in Assam. Miyah is the tonguein-cheek reference to a gentleman in Urdu. Miyah, in Assam, transformed into a term referring derogatorily to Bengali-speaking Muslims (Kumar and Andre, 2016; The Wire Staff, 2019). Reclaiming the term Miyah, poets and protesters now use the term to express their thoughts on citizenship. Some credit the origin of this form of poetry to the 1983 Nellie massacre when 2,000 Bengali-speaking Muslims were brutally killed within a few hours. Quoted here is one verse known to be the first extant Miyah poem titled "Write Down I am a Miyah" by Hafiz Ahmed, the president of the Char ${ }^{2}$ Sapori Sahitya Parishad (Daniyal, 2019). This poem was composed after the Modi Government began a National Registry in 2019, accounting for citizens in Assam while knowing fully well of its checkered history of immigration related to the formation of modern Bangladesh and the division of Bengal (see endnote). Noteworthy is the brutality with which local and national forces have excluded the most disenfranchised members of Assamese society from governance and economic opportunity, hindering them to succeed in the state policies of modernity. Ahmed's verse goes thus:

"Write down.
I am a Miya.
My serial number in the NRC is 200543.

I have two children.

Another is coming.

Next summer.

Will you hate [emphasis mine] him.

As you hate me?"

Hafiz Ahmed adapts the powerful verse of Palestinian Mahmoud Darwish who reclaims his pride, love of land, and identity with his poem ID $\mathrm{Card}^{3}$ (Hilmy, 2017). Taking the cue from such a widely recognized and powerful resistance poet is evocative of the injustice of the National Registry that disenfranchises Assamese Muslims erroneously known as Bangladeshi, casting doubt on their nationality and loyalty to

\footnotetext{
${ }^{2}$ Chars is a reference to the sandbars formed in the middle of the major regional river Brahmputra, home to labor brought in during the British Raj when Bengal was undivided. The majority of the migrant laboring class came from the Mymensingh region of northeast Bengal, now in Bangladesh. The residents of the Mymensingh area are one of the poorest and least educated of any population in Assam as also the target of the National register of citizens (Daniyal, 2019). ${ }^{3}$ Palestinian resistance poet Mahmoud Darwish's 'ID Card':
}

\footnotetext{
"Write down!

I am an

Arab And my identity card number is fifty thousand

I have eight children

And the ninth will come after a summer

Will you be angry?."
} 
the nation. It is no wonder that writer Daniyal (2019) believes that this style of protest poetry has shaken life and politics in Assam. By othering indigenous communities, the BJP's policies are exposed as anti-immigrant and anti-Muslim. One finds resonance of these dark sentiments in contemporary U.S. politics, in Trump's tactics of separating families and lodging immigrant children in cages in border states of the United States. "Hate," Hafiz Ahmed reminds us in his final verse, is a powerful word and can make those on the right side of the border become all powerful.

Another verse by emergent poet-of-dissent Grover captures protest, sorrow and anger at the formalization of the NRC in his poetry. Varun Grover declares in his verse, "Kagaz nahi dikhayenge" (we will not present our papers). Grover, a Hindu, expresses solidarity with Muslim immigrant populations who will be subject to registry once NRC is implemented nation-wide. Genres of poetry have emerged or have been revived strategically in the wake of draconian citizenship laws in the country. When the usual institutions of politics (for instance: is voting adequate?) are not able to assert adequate counterpoint, the pregnant verses of poetry have expressed youth outrage and horror at the state of the nation. Echoing Grover's sentiments is senior activist Harsh Mander who threatened to convert to Islam in protest of NRC, and well-known film maker Mahesh Bhatt who also declared non-cooperation with NRC protocols.

\section{Portals of Hope: A Creative Passage}

Roy's April 2020 essay “The Pandemic is a portal” and Sen's "A better society can emerge from the Lockdowns" (2020) take us from hopelessness to hope. A portal is an opening, a way forward. Roy writes "Historically, pandemics have forced humans to break with the past and imagine their world anew. This one is no different. It is a portal, a gateway between one world and the next." A portal can signify passage, transition, transnationalism, migration and immigration all of which are highly politicized tropes with state policies associated with them.

Sen opens the essay in question with synesthetic memories of song but his ray of hope for humanity comes with: "The need to act together can certainly generate an appreciation of the constructive role of public action. The second world war, for example, made people better realise the importance of international co-operation" (Sen, 2020, np). And we are reminded of the idealism and cooperative spirit that went into the founding of the United Nations, the World Bank and the IMF in 1948.

Roy, Sen, Appadurai, Ghosh, and Mishra have woven their politico-historical tales for readers through a worldly lens. All are suitably disturbed by the trends in authoritarianism and intolerance and its seepage in state policies unfairly impacting minoritized communities. Ghosh (2016) lays faith in a culture's imaginative resources to find solutions to extreme climate change related events--Covid-19 qualifies as such. Perhaps a way out of the conundrum of Western economic and philosophical dependency lies locally through an imaginative and philosophical coming together of disparate traditions in South Asia comprising India, Pakistan, Sri Lanka, Nepal, Bangladesh,
Afghanistan, Bhutan, Maldives. South Asia is rife with rich histories of cultural unity in the arenas of socio-political philosophy guiding a path to human co-existence. Why then must we allow political leaders to turn these powerful modes of being into ways of maintaining raw power? The hopeful proposal of a conjuncture starts with a history of trade relations with the Arab world in the seventh century C.E. and political contact in 712 C.E. with the invasion of Sindh by Mohammed Bin Qasim (Haider and Phil under supervision, 1984). The fates of several religions, namely Islam and Hinduism, that came together from the 8 th to the 17 th century with moderate, mystical ways of thinking provided us the opportunity to plumb fertile traditions of tolerance and co-existence.

The Bhakti and Sufi philosophic traditions forged semblance through common themes of devotion, a longing for a beloved in the divine, beckoned by music in their doctrines. The chief concern of the Bhakti and Sufi lines of thought is antiestablishment praxis that may be coded as political in the contemporary context. The Bhakti and Sufi traditions were able to carve a way toward communal synthesis despite a dialectical relationship between Islam and Hinduism. That form of co-existence gave rise to devotional musical traditions that are inherited by contemporary world music today. Over time, Sufi and Bhakti music metamorphosed into several branches and genres of music that had its votaries in Pakistan, India and Bangladesh. The qawwals reside in Pakistan and India, and the bauls, wandering mystic minstrels reside in West Bengal in India, and in Bangladesh. Qawwals and bauls shunned institutionalized religion while adhering to their own rules of mysticism. The bauls, despite border restrictions and threats from mainstream Islam, wander singing Vaishnava inspired and Sufi inspired devotional music. The qawwals usually sing in dargahs, shrines of "pirs" (learned persons), or Sufi saints. Their geographic separation from mosques or mandirs, havens of institutionalized religion was normalized until modern, post-1947 discourses of Islamic and Hindu nationalism (exacerbated by the Trumpian Global War on Terror and Modi's Hindutva) fanned the fires of communalism. Dargahs came to be seen as too Islamic in an era of Hindutva politics whereas the dargah was perceived as too secular for an equally rapidly fundamentalizing Islam of the $21^{\text {st }}$ century (Katju, 2014).

Just as the Miyah poets are perceived as shaking up Assam, the Sufi/Bhakti poets are trying to survive threat of killings, and beatings. Their resilience and syncretism are shaken but intact as an exemplar of dissent for us to admire and adopt. While physical destruction through Covid-19 pestilence will take its course, the ideological divides must not continue to erode our ability to co-exist with our neighbors nor marginalize those who are subject to economic or religious intolerance. The reality of the Citizen Amendment Act, Article 370, The Domicile Act in Kashmir, the National Register of Citizens and the National Population Register are a warning call for all who value the exhilarating cultural hybridity and transnationalism in Indian and South Asian custom. Global elite leaders in India and abroad: Brazil, Philippines, Hungary, United Kingdom., United States, and Russia are succeeding in 
"undoing many democratic structures, values and traditions" (Appadurai, 2020a). In the end, we are surrounded by our collective creativity despite foreboding political (reference: strongman authoritarian politics), extreme climate events and pandemic scenarios. The Sufis, the Miyahs, and the new poets of protest show a way for us to think of problems of contemporary (derelict) rural and (dense) urban life in ways that surpass the cupidity of historical times as during colonialism, neo-liberal economic policies, formation of the nation-state and modern-day governance. These creative channels of thinking collectively, steer humanity in a direction that Roy, Ghosh, Appadurai, Sen and Mishra urge us to, for the continued existence of collective protest. This is a direction that is not meek or subtle, a mobilization of citizens, marginalized and beaten down, although moved to create social change by electing political leaders who represent

\section{REFERENCES}

Al, J. (2020). The stream: what does the domicile law mean for Kashmir?. Available at: https://www.aljazeera.com/programmes/thestream/2020/ 06/domicile-law-kashmir-200610143308394.html (Accessed July 20, 2020).

Appadurai, A. (2020). Coronavirus won't kill globalization. But it will look different after the pandemic, May 19, 2020. Time. Available at: https://time.com/ 5838751/globalization-coronavirus/ (Accessed May 30, 2020).

Appadurai, A. (2020a). We are witnessing the revolt of the elites, 22 April, 2020. The Wire. Available at: https://thewire.in/politics/populism-elite-narendramodi-donald-trump (Accessed April 25, 2020).

BBC (2019). Assam NRC: what next for 1.9 million 'stateless' Indians?. BBC News. Available at: https://www.bbc.com/news/world-asia-india-49520593 (Accessed September 1, 2020).

Biswas, S. (2020). Manmohan Singh's 'three steps' to stem India's economic crisis. Available at: https://www.bbc.com/news/world-asia-india-53675858? fbclid=IwAR2GAnS3SfWCit0M3rQ1-fG7xXeAq670w4it0qUXPxV1XIQW mADiqXIGFAQ (Accessed August 10, 2020).

Connah, L. (2020). Kashmir: new domicile rules spark fresh anger a year after India removed region's special status, July 29, 2020. The Conversation. Available at: https://theconversation.com/kashmir-new-domicile-rules-spark-fresh-anger-ayear-after-india-removed-regions-special-status-142696 (Accessed September 25, 2020).

Daniyal, S. (2019). 'I am Miya': why poetry by Bengal-origin Muslims in their mother tongue is shaking up Assam, July 14, 2019. Scroll. Available at: https://scroll.in/article/930416/i-am-miya-why-poetry-by-bengal-originmuslims-in-their-mother-tongue-is-shaking-up-assam (Accessed April 1, 2020).

Dave, D. (2020). Who will take responsibility for the human tragedy unfolding in democratic India?. 28 March 2020. The Wire. Available at: https://thewire.in/ rights/who-will-take-responsibility-for-the-human-tragedy-unfolding-indemocratic-india (Accessed March 29, 2020).

Express News Service (2020). Migrant workers caned in Guntur after rushing out of relief camp in bid to return home. New Indian Express. Available at: https:// www.newindianexpress.com/states/andhra-pradesh/2020/may/16/migrantworkers-caned-in-guntur-after-rushing-out-of-relief-camp-in-bid-to-return-home2144154.html?fbclid=IwAR20RixfbFEtfJag-BwqfEmM5CC1sasqelfTQXrj_ mM3c7Pu5bvCK2V8L8E (Accessed May 30, 2020).

Gettleman, J. (2020). Coronavirus crisis shatters India's big dreams. Available at: https://www.nytimes.com/2020/09/05/world/asia/india-economy-coronavirus. html (Accessed September 5, 2020).

Ghosh, A. (2016). The great derangement: climate change and the unthinkable. Chicago, UK: The University of Chicago Press.

Goodman, A. (2020). "Chaotic Situation": India begins Lockdown of 1.3 billion residents as coronavirus pandemic spreads, March 26, 2020. Democracy Now. their socio-cultural and political predilections. Ghosh (2016), Appadurai, 2020a, and Mishra (2020), in their writings, unveil the political and moral failings of the Western powers who, have not devised a way to share national and global power, even in a postcolonial and globalized world. In other words, traditional colonial structures have not dismantled because the usual suspects of global power (the United Kingdom, United States, other European nation-states) have not shouldered the mantle of leadership very well.

\section{FUNDING}

A grant from the National Research Foundation of Korea (NRF2017S1 A6A3A0209749) has supported the research for this essay.

Available at: https://www.democracynow.org/2020/3/26/amitav_ghosh_india_ coronavirus_lockdown (Accessed March 30, 2020).

Gupta, S. (2020). Exhausted migrants fell asleep on tracks. 16 run over by train. Available at: https://www.ndtv.com/india-news/15-migrant-workers-run-overby-train-in-maharashtra-2225184.

Haider, S. R., and Phil under supervision, M. (1984). Relations of the Bhakti saints with Muslim sufis, $16^{\text {th }}$ and $17^{\text {th }}$ centuries. Aligarh, UP: Dr. Jagatvir Singh Agre, Aligarh Muslim University. Available at: https://core.ac.uk/download/pdf/ 144516397.pdf (Accessed August 1, 2020).

Hilmy, S. (2017). "ID card” by Mahmoud darwish-a translation and commentary. Available at: https://www.wrmea.org/017-november-december/id-card-bymahmoud-darwish-a-translation-and-commentary.html (Accessed January 1, 2021).

Katju, M. (2014). Dargahs and sufis, times of India blogs. Times of India. Available at: https://timesofindia.indiatimes.com/blogs/satyam-bruyat/dargahs-andsufis/ (Accessed February 10, 2020).

Khosla, M. (2020). With freedom at stake, courts are collapsing: in Hungary, Turkey and India, the courts have turned into silent bystanders and complicit actors. New York Times. Available at: https://www.nytimes.com/2020/09/09/ opinion/hungary-turkey-india-courts.html.

Kumar, A., and Andre, A. (2016). Protest poetry: Assam's Bengali Muslims take a stand. Available at: https://www.aljazeera.com/features/2016/12/23/protestpoetry-assams-bengali-muslims-take-a-stand (Accessed December 23, 2016).

Levantesi, S. (2020). Amitav Ghosh: 'I suspect there will be a huge wave of novels about the pandemic'. Mint. Available at: https://www.livemint.com/ mint-lounge/features/-i-suspect-there-will-be-a-huge-wave-of-novels-about-thepandemic-amitav-ghosh-11589638359319.html (Accessed June 1, 2020).

Maqbool, U. (2020). J\&K's controversial new domicile law faces a legal challenge, August 8, 2020. The Wire. Available at: https://thewire.in/government/ jammu-and-kashmir-domicile-rules-legal-challenge (Accessed September 26, 2020).

Menon, A. (2020). 90\% workers lost livelihood, 94\% ineligible for govt relief: study, 9 April, 2020. Available at: https://www.thequint.com/news/india/ covid19-lockdown-economy-impact-construction-workers (Accessed June $10,2020)$

Mishra, P. (2020). Flailing states: Pankaj Mishra on Anglo America. London Review of Books. (London, UK):Available at: https://www.lrb.co.uk/the-paper/v42/n14/ pankaj-mishra/flailing-states (Accessed July 16, 2020).

Noble, S. (2020). The loss of public goods to big tech. Available at: https://www. noemamag.com/the-loss-of-public-goods-to-big-tech/ (Accessed July 20, 2020).

Roy, A. (2020b). Arundhati Roy: India's Hindu Right are willing to bury democracy. Available at: https://www.jacobinmag.com/2020/10/arundhatiroy-india-bjp-modi-delhi-protests-cremation (Accessed August 1, 2020).

Roy, A. (2020a). India's day of Shame. Aug. 5, 2020. The Wire. Available at: https:// thewire.in/rights/august-5-kashmir-ayodhya-bhoomi-pujan-ram-mandir-china (Accessed August 7, 2020) 
Roy, A. (2020c). The pandemic is a portal. Financial Times. (London, UK) Available at: https://www.ft.com/content/10d8f5e8-74eb-11ea-95fefcd274e920ca (Accessed April 15, 2020).

Sardesai, R. (2020). Amitav Ghosh exclusive: cyclone in covid times. May 29, 2020. India Today Available at: http://book-news.org/bengals-sundarbansdevastated-by-cyclone-amphan-author-amitav-ghosh-discusses-climate-change (Accessed July 10, 2020).

Sen, A. (2020). A better society can emerge from the Lockdowns. April 15, 2020. Financial Times. Available at: https://www.ft.com/content/5b41ffc2-7e5e-11eab0fb-13524ae1056b (Accessed April 20, 2020).

Sharma, S. (2020). India cannot fight a pandemic with police lathis: it must ensure people have food-and dignity 13 April, 2020. Scroll. Available at: https://scroll. in/article/958993/india-cannot-fight-a-pandemic-with-police-lathis-it-mustensure-people-have-food-and-dignity 2020 (Accessed May 1, 2020).

Staff, S. (2020). 'I haven't eaten in two days': migrant workers unable to return home, protest in Bengaluru, May 5, 2020. Scroll. Available at: https://scroll. in/video/961056/i-havent-eaten-in-two-days-migrant-workers-unable-toreturn-home-protest-in-bengaluru?fbclid=IwAR0RIiI5S9u03P9b29dzpdCRxqMPq209qVKPrCNofmDF7ZRfM0kLI7qnGc (Accessed May 15, 2020).

The Lancet. (2020). COVID-19 in India: the dangers of false optimism. Lancet. 396 (10255), 867-867. doi:10.1016/S0140-6736(20)32001-8
The Wire Staff. (2020a). Academics, rights activists condemn umar khalid's arrest, Accuse Delhi Police of 'Witch Hunt, 14 September, 2020. Wire. Available at: https://thewire.in/rights/umar-khalid-arrest-condemned (Accessed September 20, 2020).

The Wire Staff. (2019). Assam: ten poets, activists booked for poem on citizenship row, July 12, 2019. The Wire. Available at: https://thewire.in/rights/miyahpoetry-assam-nrc (Accessed January 1, 2020).

The Wire Staff (2020). Delhi violence: police raid AISA student leader's home, seize phone. Available at: https://thewire.in/government/delhi-violence-aisastudent-leader-kawalpreet-kaur-raid (Accessed May 3, 2020).

Conflict of Interest: The author declares that the research was conducted in the absence of any commercial or financial relationships that could be construed as a potential conflict of interest.

Copyright $\odot 2021$ Kapoor. This is an open-access article distributed under the terms of the Creative Commons Attribution License (CC BY). The use, distribution or reproduction in other forums is permitted, provided the original author(s) and the copyright owner(s) are credited and that the original publication in this journal is cited, in accordance with accepted academic practice. No use, distribution or reproduction is permitted which does not comply with these terms. 